\title{
Modern Literature after the 1960s in Korea
}

Abstract (English): Since the beginning of the 1990s in Korea, the category and definition of new generation literature have become the topic of heated debate. One may understand this tendency as 'generation severance', 'alienation between social classes', or the 'consumptionoriented culture of the masses'. Here, we call the literary youth born in approximately 1960 'the new generation'.

In literature, the new generation refers to the appearance of a new culture and way of thinking. This generation passed their childhood in the 1970s and faced no such great difficulties as their parents combating poverty. However, they grew up under the indirect influence of a dark political outlook and suppression. Generally, they have a great affection for the culture produced by mass media.

If we compare their development process with the literary stream in Korea, the $1960^{\mathrm{s}}$ could be defined as the era of literature for independence and strong self-awareness, the 1970 s as the era for people, the 1980s as the era for the rights or emancipation of labour, and the 1990s as the era of new generation literature. Meanwhile, the appearance of the 'Korean Wave', or so-called 'Hallyu', has become one of the most beloved popular cultural phenomena both in Asia and in other countries since the late 1990s.

Abstract (Korean): 특히 문학에서 1990년대 후반의 신세대가 새로운 문화의 등장과 새로운 사고로 특징되는 배경은 70 년대에 유년시절을 그들의 부모세대와 달리 큰 어려움을 겪지 않고, 경제적으로도 궁핍하지 않게 성장할 수 있었기 때문일 것이다. 달리 표현하면, 이들은 어려운 정치적 환경과 사회적 억압을 간접적으로 겪었다. 대신 일반적으로 이들 세대는 대중매체에 의해 생산된 문화에 빠져들 수 있었다. 간추려서 이들의 성장과정을 통해 한국의 문학적 흐름에 비교한다면, 60 년대는 독립과 자의식이 강한, 70 년대는 사람을 중시하는, 80 년대는 노동의 자유와 권리를 위한, 그리고 90 년대는 변화를 원하는 신세대로 불릴 수 있다. 이러한 배경과 토대에서 비로소 아시아를 비롯해서 세계에서 가장 사랑 받는 대중문화인 '한류'가 생겨날 수 있었다고 본다.

따라서 여기에서는 5 가지의 범주를 통해 현대 한국문학을 보다 집약적으로 진단하고자 한다. 즉 60 년대를 일본으로부터의 해방과 한국전쟁 이후의 분단문학으로, 70 년대를 산업화와 민주화 문학으로, 80년대를 노동의 문학으로, 90년대를 산업화 이후의 현대문학으로, 그리고 마지막으로 90년대 후반부터를 신세대 문학으로 규정하고자 한다. 이를 위해 본 연구의 방법은 사회정치적 
현상에 근거하며, 언급되는 작가와 작품 역시 이와 관련된 것을 중심으로 진단하고자 한다.

Keywords: liberation, division, Korean War, Korean literature, industrialization, democratization, new generation.

\section{Introduction}

Last year, 2015, marked the 70th anniversary of Korea's independence from Japanese occupation and the division of the Korean peninsula into North and South. This liberation and division occurred almost simultaneously. The state of division, a symbol of modern human tragedy, has continued for 65 years since the Korean War in 1950. During this time, Korean literature has acted as a window into Korea's turbulent and chaotic modern history. Through different perspectives and narrative techniques, Korean literature has sincerely represented the lives and concerns of Korean people. For this reason, it would not be wrong to define Korean literature as 'a literature of division'. Notwithstanding this fact, time is required to overcome the scars and pain of the fratricidal war caused by such division.

Since national division in the post-war years of the 1950 s, South Korea has been continuously linked by the following events: the military dictatorship, 'Student Revolution' of April $19^{\text {th }}$, and rapid industrialization in the 1960s-1970s; the dawn of depoliticization and new generation writers in the 1990s; and the postmodern and digital age, or even 'Korean Wave', of the early 2000s. Through these eras, Korean literature can be characterized and even evaluated from very different perspectives. Meanwhile, modern Korean literature has developed under conditions of unprecedented social and political turmoil.

In other words, Korean modern history can be interpreted through the lenses of imperial interventions, colonization and de-colonization, national division and the Korean War, dictatorship and democratization, and economic development and globalization. Its geopolitical conditions have demanded that Koreans maintain their own historical, linguistic, and cultural identity in very difficult circumstances. Thus, during these times, the cultural role of literature was particularly important.

Therefore, this paper will hereafter verify the following five categories: liberation from Japan and division literature after the Korean War, the literature of the post-war era and democracy in the 1960s, industrialization and democratization in the 1970s-1980s, Korean modern society in the 1990s, and the new generation literature from the late 1990s. Thus, the method of study used in this paper is focused on socio-political phenomena, and according to the need, the related individual writers and works are here cited. 


\section{Liberation, division, and the Korean War}

Korea was liberated from Japanese occupation in August 1945, but due to the intervention of the U.S.A., the Soviet Union, and China, Korea was subsequently divided into two countries: South Korea and North Korea. Therefore, all Korean literature from 1945 onwards can be called 'division era literature', and most Korean literature remains heavily influenced by this division. However, the tragedy of division provided a great deal of inspiration and material that allowed Korean literature to develop.

The Korean War in 1950 is certainly one of the most important events in Korean literature, and, accordingly, Korean literature can be divided into three categories based on the following chronological order: 'space of liberation literature' (1945-1950), 'wartime literature' (1950-1953), and 'post-war literature' (1953-1959). During these periods, writers tended to focus on the social reality of confusion and devastation, and tried to depict the image of people wandering for survival. The turbulent times of the division era, i.e. the severance of North and South meant that at that time people could no longer go back and forth across the border. As an inevitable consequence, a new era of literature was created by many writers, who fled from the North and settled in the South. As notable writers of this division literature, Sunwon Hwang, Changsop Son, Yonghak Chang, Inhun Choi, Hocheol Lee, Chunghui Choe, Kyongni Pak, and others are here mentioned.

Among these writers, S. Hwang depicted his personal experiences in North Korean society before the Korean War and in South Korean society after the Korean War in his novel The Descendants of Cain. In addition, his Trees on a Slope presents the lives of young people trying to deal with the war and cope in the destruction of its aftermath (Jonghoi Kim 2015, p.31). Meanwhile, Ch. Son and Y. Chang described the immense suffering of the late 1950s in particularly sharp detail, while writers such as I. Choi and $\mathrm{H}$. Lee narrated faithfully and anew the same subject matter in the context of the relationship between North and South. Surprisingly, these circumstances were also described by $\mathrm{Ch}$. Choe and $\mathrm{K}$. Pak with the heightened sensitivity of female writers at a time when they had come to be viewed as the leading lights of their era.

However, beginning in the 1960s, the stream of literature became increasingly complex as the conditions in South Korean society gradually began to recover some social stability. From that time to today, methods of referring to literature continue to emerge, such as 'divided literature', 'literature of separation', 'literature of the industrialization era', and 'new generation literature', etc. So to speak, the creative and thematic perspectives adopted in Korean literary works from the 1960 s onwards have as their core issues division, industrialization, and democratization. 
Since most writers experienced war, famine, and devastation during their childhoods, themes based on these experiences are still considered to be the mainstream of Korean literature. The literary works of Wonil Kim, Sangguk Cheon,Sungwon Han, and Munyol Yi are typical examples. They lived through the war as children and grew up to revive memories of their desolate childhoods in their works. ${ }^{1}$

\section{Literature of the post-war era and for the democracy in the $1960 \mathrm{~s}$}

'Post-war literature' is both a concept and category used in modern Korean literature. It remains an ongoing issue since the only armistice agreement was signed in 1953, and the influence of the wartime experience continues to exist today. Therefore, it is better to describe mid-1960s Korean literature as 'first-phase post-war literature'. The concept of 'post-war' has an overlapping nature to Korean people, since it refers to both the end of World War II, which led to the independence of Korea, and also to the end of the Korean War, which divided the Korean peninsula into two different countries.

While the young writers who grew up in South Korea secured hegemony in Korean literature, there was also a group of writers, poets, and critics, who had come from the North in order to survive during the war. Strangers to the new environment and engulfed by the reality of deep disharmony in the South owing to economic lack, cultural upheaval, and political corruption. Naturally this group expressed this sense in the discourses of their work, which could be sorted into three basic forms of discourse: return to one's hometown, acclimatization to new surroundings, and the search for another idealized homeland.(Minho Bang 2015, pp.34-35) On the other hand, South Korean writers tried to emphasize the inherent value of literature.

The catastrophic damage inflicted by the Korean War shifted Korea into a completely different society than before, and Korean literature transformed into the 'first-phase of post-war literature'. The abovementioned Sunwon Hwang is a typical example of a writer from this era, demonstrating the destructive influence of ideological conflict and war on young people in such novels as The Descendants of Cain. Inhun Choi expressed the unique awareness of a writer who had fled his hometown in his work The Square, while Hochol Lee's Petit Bourgeoisies sought the establishment of a new Korean society after the war. Many of the prominent post-war literary works were written by female authors, such as Kyongni Pak and Chunghui Choe who, in their works, depicted the violence inflicted on women during the wartime. In addition, short stories by Shinjae Kang, Malsook Han, and Jangsoon Sohn convey a subtlety of moral awareness.

Korean literature in the 1960 s can be summarized into the themes of 'aftermath of the 4.19 (April 19th) Revolution' and 'introspective fighting back'. The 4.19 Revolution gave Korean people the hope of freedom and 
democracy, but this dream was shattered in the very next year by the 5.16 (May 16th) military coup. In this era, Korean literature strove to combat the cruel reality. Seungok Kim's Journey to Mujin and Chongjun Yi's The Wounded expressed the despair and hopelessness of Korean society after the coup. In Ch. Yi's The Wounded, anti-communist ideology is described in detail as an effective means to unite the nation to accomplish the goal of 'modernization of the fatherland', which was the most urgent call of the Park regime in the 1960s. That issue was directly associated with the matter of how to describe the Korean War in cultural productions of that era (Jimi Kim 2013, pp.73-75).

Some writers went beyond the trend of anti-communist or anti-war polemics and tried to provide a more balanced perspective on the subject. In poetry, Sooyoung Kim and Dongyup Shin depicted the spirit of the 1960s, but while S. Kim focused on the negative aspect and atmosphere of society, D. Shin approached social issues with traditional values and teachings (Yonghee Hong 2015, pp.36-37). It can be defined here that Korean literature from the maelstrom of the Korean War to the period of the 1960s took up the causes of stability and the fight for freedom and democracy in people's lives.

However, at the same time, Korean society changed rapidly after the 4.19 Revolution in 1960 when students became the driving force in the fight against Rhee's dictatorship and the 5.16 military coup. Of course, the desolate literature of the early 1960s opened a new literary world, followed the social trends, and displayed a diverse social consciousness, from political democracy to workers' rights. More specifically, two writers are representative of this era: Seungok Kim tried to rediscover a lyrical sensibility in his short story, while Chongjun Yi expressed the interrelation between self and reality by a single pathological phenomenon. In addition, a number of works such as Sokyoung Hwang's Strange Land, Heunggil Yun's The Man Who Was Left as Nine Pairs of Shoes, and Sehee Cho's A Dwarf Launches a Small Ball addressed the social issues of the time, including the side effects of rapid industrialization, by comparing rural and urban areas in a more direct way.

Thus far, most of the explanation has dealt with novels, as stories provide a more concrete and realistic description when it comes to identifying the interrelation between social and literary fiction through narrative. However, to discuss literature solely from the perspective of novels is not a reasonable standpoint. In those days, there were also a great deal of notable poets; however, poetry is more difficult to discuss in terms of social interaction than novels, even if there do exist some poets who represent this era.

Sooyoung Kim, for example, expressed the zeitgeist in his poem Blue Sky, while Dongyup Shin did so in his collection Asanyeo. Above all, from 1970 onwards, poet Jiha Kim wrote a poem that represented the voice of popular resistance. With his Five Thieves, he forged a new horizon in the history of poetry. Owing to his serial poetry, he became a legendary figure among both, the many poets at that time as well as for a later generation. However, he was 
eventually imprisoned by the Korean government for a long time, sparking the so-called 'engagement' in Korean literature, which then became widespread.

It is also interesting to note a poet who diligently transformed everyday language into poetry. As a member of the 4.19 Generation, Kwangkyu Kim ${ }^{2}$ has broadened the horizons of Korean poetry by presenting us with the new genre of so-called everyday poetry. Let us observe his poetics through an interview he conducted with a journalist.

(Journalist) Ahn: On reading your poems, readers get clues about certain thoughts and realizations drawn from everyday life since it is central to your poetry. You mentioned the 4.19 Generation. Are we to understand that this pursuit of everydayness is connected to you being part of that generation?

(Poet) Kim: That's right. The rise of everydayness is an important clue, whether in poetry or prose. Take novels for example. The petit bourgeois started appearing in the novels of the post- 4.19 Generation instead of the heroic protagonists that appeared in earlier generations. A similar transformation of the poetic ego can be seen in my fourth poetry collection, Like Someone Fussing and Fretting (1988) and my fifth collection, Aniries (1990). ${ }^{3}$

Through his poetic experimentation, which began in 1979 with his first collection of poems, The Last Dream to Drench Us, K. Kim has given meaning and value to the domain of the petit bourgeoisie who had not previously received attention.

\section{Industrialization and democratization in the 1970s-1980s}

Korean literature in the 1960s can be summarized into the themes of 'influence of the 4.19 Revolution', 'aftermath of the 5.16 military coup', and 'introspective fighting back'. In other words, the aspirations of the 4.19 revolution in 1960 had been trashed within a year by the military coup of 1960. Accordingly, the failed revolution was internalized in the literary world and began to play out as a literary 'fight back' (Yonghee Hong 2015, p.36).

Despite such circumstances, in the early 1960 s, Korean society began to change dramatically with its rapid industrialization. Despite the outstanding economic growth, before long it had created many side effects, such as the unequal distribution of wealth, urban-rural conflicts, and dehumanization of the labour force. Therefore, Korean literature in the 1970s tried to focus on these social issues. The new tendency of note in literature from the beginning of the 1970s was the social emergence of conflict between the proletariat class and the bourgeoisie, and workers' issues became the main subjects of Korean literature. For example, in Sokyong Whang's Strange Land, we can find a detailed account of wage exploitation and the poor conditions in the daily lives of workers. He also examined the lives of wandering labourers 
and their loss of emotions caused by the dismantling of fishing and farming villages in The Road to Sampo (Chanje Wu 2005). ${ }^{4}$

The man in the dog-fur hat paused a moment and turned around, but then kept on walking. Yŏng-dal ran after him. When he caught up with him, he said, gasping for breath, 'Let's go together. I'm going in the same direction as you are, at least up to Wŏlchul'. [*] 'Well, one gets used to that sort of thing', said the other man. 'Do you have any idea how far Sampo is?' At least several hundred li, that is, to the sea coast, and then we have to take a boat'. 'How long has it been since you left Sampo?' asked Yŏng-dal. 'Over ten years', answered the other man, and he continued, 'There won't be anybody who will recognize me there'.'Why do you want to go back then?' asked Yŏng-dal. 'For no particular reason', said the other man. 'As I'm getting old, I just feel like visiting it'.

To be more concrete, the modern industrialization of Korea in the 1970s was dependent on rock-bottom wages, export-driven production, and concentration on heavy industries. As a result, the economic growth brought to the fore the backwardness of rural villages, the great gap between urban and rural lives, etc. These facts are connotatively dealt with in his novel.

At that time, the anxiety incurred under the economic oppression and inequality sought its best expression in S. Hwang's Strange Land and Sehee Cho's A Dwarf Launches a Small Ball. These novels depict wandering labourers who suffer under the deepening economic inequality and factory workers who are killed while fighting against it. Here, the imagining of the anxiety shows itself as a political unconsciousness that longs for economic equality.

In other words, the collective unconsciousness of deep anxiety can be easily found in the novels of the 1970s. However, according to the writer's attitude of confronting the given situation, the imagining of anxiety shows itself differently as political unconsciousness yearning for freedom, equality, unification, or true self-identity.

With regard to rural devastation, Sungwon Han demonstrated the rapid disappearance of rural villages in his work, In the Heart of the Mountains. $\mathrm{He}$ also dealt mainly with the folk character and vitality of the fast disappearing farming villages by using rustic language and rural sentiment. Meanwhile, other novels, such as Elegy for Jaragol by Kisook Song and Dream of Lingering Sorrow, The Ballad of Kalmori, and Our Neighborhoodby Munku Lee, described the awakening and adaption of rural villagers to the structural inconsistency and pressure of society. In such stories, for example Ilnam Choi's Seoulites, the main plot focuses on the negative aspects of industrialization, human alienation, boundless materialism, and moral hazards at work. In summary, the social conditions of class alienation and the loss of basic humanity are described in detail with deepest sympathy. 
On the other hand, the poetry of the 1970s pursued an aesthetic approach through the form of Korean lyrical forms and styles, which were adopted from the traditional narrative of pansori, such as Jiha Kim's Five Thieves (Youngsoon Song 2007). ${ }^{6}$ Jiha Kim created a cutting satire of the structure of oppression instituted by the dictatorship and decadent corruption of the age. This marked a particularly important transformation in the field of Korean literature and arts. One may say that this new exchange signified both autonomy and identity in the field of literature.

However, in the 1980s, Korea tragically experienced the Gwangju Democratization Movement in order to stand against the military regime. For the time being, therefore, literature could not help but be coloured by the concept of 'literature as a social movement', and gradually had to fight against the military regime in power. The military government was finally deposed in 1987 and the political maelstrom settled into peace. After that, Korean literature was able to enjoy freedom of speech. Furthermore, the collapse of the Eastern bloc in Europe and the end of the Cold War era relieved the social atmosphere, so that writers could elevate their own diversity and pluralism without restriction.

\section{Korean modern society in the 1990 s}

Through these tumultuous stages, Korean literature in the 1990s began to develop very different sensibilities and techniques than those of the 1980s. Poets and novelists were able to elevate their own diversity and plurality without government restrictions, and many changes occurred in social conditions, above all in the transition from print and analogue media to digital and image culture media. Thus, the literary and arts environment incurred a change and was concurrently confronted with differences from the past.

One of the writers who marked this change in Korean literature was Youngha Kim. He took a deep interest in describing various aspects of social change in Korea, in a novel that was distanced from so-called storytelling and represented a transformation in Korean literature towards an expanded awareness of other countries beyond the Korean peninsula. Some other writers, such as Mingyu Park and Kiho Lee, who had manifested the shift from traditional methods of life to the digital era, gave readers descriptions of daily life in the so-called post-modern society in their novels. Of course, these writers could not be said to represent Korean literature in itself; however, in the transformation of the history of Korean literature, they wrote meaningful works that reflected the changing times (Jonghoi Kim 2015, p.33).

This change in Korean literature was derived from both inside and outside, with the change in society and the South-North Korean relationship. Furthermore, 'the era of women's literature' started after the 1990s with the rise of the women's rights movement, and some notable writers such as 
Kyungsook Shin, Insuk Kim, Hajin Seo,Kyungnin Jon, Kyungran Jo, and Kang Han represent a more meticulous approach to literary creativity. They pioneered this era and many readers eagerly embraced their works.

With the end of the Cold War, South Korea was successfully transformed into a developed country. Korean literature also rapidly changed shape and was liberated from its predetermined concepts. Instead of national division and political conflicts, writers tried to emphasize the problems of a postindustrial society. Youngha Kim ignited the change in Korean literature in the 1990s with his debut novel I Have the Right to Destroy Myself.

They never ask questions like, 'Have you ever felt the urge to kill someone?' And obviously they never wonder, 'How do you feel when you see blood?' They don't show the interviewees David's or Delacroix's paintings and ask them their thoughts. Instead, the interviews are filled with meaningless chatter. But they can't fool me; I catch the glimmer of possibility in their empty words. I unearth clues from the types of music they prefer, the family histories they sometimes reveal, the books that hit a nerve, the artists they love. People unconsciously want to reveal their inner urges. They are waiting for someone like me. ${ }^{7}$

Y. Kim presents a so-called 'suicide advisor' as his narrator. The narrator argues that a life controlled by the big Other is possible; accordingly, the only autonomous action is voluntary death. In a strange post-modern age, his paradoxical protagonist signals the passing of Korean society over a new horizon. Furthermore, in his novel, the writer tries to demonstrate the peculiarity of Korean modernization and modern society through the perspectives of Korean people from various backgrounds: an immigrant worker, a North Korean spy, a serial killer, etc. (Bosun Ryoo 2015, pp.40-41).

Mingyu Park is another notable writer of the 1990s whose work was inspired by foreign pop culture. With the mixture of the Korean traditional ego, he illustrated the foreign pop culture with his own unique taste. Even today, he brings many ideas and concepts from the latest movies, such as The Avengers and Mad Max, to his work. Kiho Lee also demonstrates a unique perspective on post-modern society, and his latest work The World History of Second Sons is regarded as one of the greatest Korean novels of the $21^{\text {st }}$ century. On the other hand, Myeongkwan Cheon criticized the modern political structure through his unusual yarns in his breakthrough work, Whale. Lastly, Korean literature encountered a wave of neo-liberalism, and this wave heavily influenced Korean literature's reflection of modernity.

In the 1990s, Korean female authors started to participate actively in Korean literature, as the focal point of literature moved from political aspects to scenes of more personal and daily life. Some female writers, such as Heekyung Eun and Seongnan Ha, attempted to examine existence in the context of a rapidly changing society, while Kyongnin Jon and Kang Han attempted to investigate sexuality as a method to break from rationalism. 
In H. Eun's novel $A$ Gift from a Bird, the protagonist is divided into two characters in order to provide an exhaustive and objective observation in the story. Similarly, S. Ha utilizes the perspective of a cold observer to amplify the dark side of modern life where all communication has been severed. On the other hand, Hyeyoung Pyun focused on our diminishing existence in her early works, but has recently emphasized that the idea of our utter vulnerability due to the possibility of unexpected disasters gives meaning to our existence. Lastly, Sunghee Yoonhas tried to seek a new meaning for existence by breaking away from the common attitude towards life (Soojeong Shin 2015, pp.44-45).

In terms of sexuality and female instinct, K. Jon is the most notable female writer to utilize these concepts in literature. She has embodied women's desire and sexual sense for deviation and escape in her works, such as The Goat Herding Woman and Nighttime Spiral Staircase. K. Han's The Fruit of My Woman shows the fundamental desire that lies in the woman's instinct, and Woonyoung Chun's Needle emphasizes the veritable feast of this female desire using the symbol of a needle tattoo as an object for masculine voyeurism. The female writers of the 1990s have opened up a new realm in Korean literature in a distinctive style and fashion, and are still creating a new chapter in Korean literature.

\section{New generation literature from the late 1990s}

Here a different perspective related to Korean culture is necessary. Since the appearance of the 'Korean Wave' in the late 1990s, Korean popular culture has become one of the most beloved popular cultures both within and outside of Asia. In comparison with Korean literature, many have recently come to prefer Korean pop-culture, which they perceive as something new and trendy, as well as something that contains Asian values and emotions (Sangyeon Sung 2008, p.11). However, the influence and relationship between Korean literature and culture could be studied together with other fields. Thus far, it is very important for the understanding of literary contents that are closely linked to the so-called K-Pop culture. In summary, Korean literature has, to date, supplied cultural nourishment, e.g. even in the Korean Wave of today.

The introduction of a new generation to literature means the appearance of a new culture and a new way of thinking. This generation passed their childhood in the 1970s with no such great difficulties as their parents combating poverty, and then grew up indirectly influenced by the new political outlook and suppression. Generally, they have a great affection for the culture produced by mass-media. If we compared their development process with the literary stream in Korea, the 1960s could be defined as the era of literature for independence and strong self-awareness, the 1970s as the era for people, 
the 1980s as the era for the rights or emancipation of labour, and the 1990s could be called the new generation literature.

Ha Yu, Seungok Kim, Jeongil Chang, Ilmun Park, and Inhwa Lee are classified as post-modernists, and the narrative technique used in their works is characterized as pastiche, literary piracy, parody, and kitsch. Using a sneering and nimble technique, they describe the urban civilization as a kaleidoscope. Moreover, the themes of new-generation literature include self-denial, nihilism, and resignation.

\section{Conclusion}

In the age of the new generation, the nihilism and lamentation of young urbanites, and their powerlessness in the face of a mammoth urban civilization are represented in several areas of daily life. In general, there are two ways to depict the mass cultural element in literature, which are not only borrowed in their works but also used for the purpose of criticizing mass culture. One is deeply rooted in the mass culture that attracted their sensitivity at the time when screen-media was widespread, and the other is concerned with the mass culture willing to dissolve the old-fashioned view of literature by reflecting the decadence of a post-industrial society. There is no denying that the newgeneration literature reflects mass culture in the above-mentioned two ways.

In conclusion, the literary significance of new-generation literature, which has already opened up a new sensibility in literature, must be discussed more seriously. At the same time, the new generation, known as the 'kitsch generation', must transcend the dogma or self-complacency caused by the theoretical superficiality of mass culture, as well as taking a realistic view in harmony with today's condition. I believe the function of literature can be best understood through the process of compromise and research based on the history of Korean literature.

\section{References}

\section{Works and Books, edited volumes:}

Alexander, J., 1987. Twenty Lectures: Sociological Theory since World War II. New York: Columbia University Press.

Cheon, M., 2004. Whale. Paju: Munhakdongne Publishing Corp.

Cho, S., 2006. A Dwarf Launches a Small Ball. Translated by Ju-Chan Fulton. Honolulu: University of Hawai'i Press.

Choi, I., 1975. Seoulites. Seoul: Sedemungo.

Choi, I., 1985. The Square. Translated by Kevin O'Rourke. Barnstaple: Spindlewood. Chun, W., 2001. Needle. Paju: Changbi Publishers, Inc. 
Eun, H., 2014. A Gift from a Bird. Paju: Munhakdongne Publishing Corp.

Han, K., 2000. The Fruit of My Woman. Paju: Changbi Publishers, Inc.

Hwang, S., 1983. The Road to Sampo and Other Korean Short Stories (Modern Korean short stories No.9). Translated by McHale Brendan. Sisayongosa Publishers/ Pace International Research, Inc.

Hwang, S., 1997. The Descendants of Cain. Translated by Jimoon Suh and Julie Pickering. New York: M.E. Sharpe.

Hwang, S., 2005. Trees on a Slope. Translated by Bruce Fulton and Ju-Chan Fulton. Honolulu: University of Hawai'i Press.

Jon, K., 1996. The Goat Herding Woman. Paju: Munhakdongne Publishing Corp.

Jon, K., 2015. Nighttime Spiral Staircase. Seoul: Thinking Tree Publishing, 1998.

Kim, J., 2001. Five Thieves. Translated by Wonchung Kim and James Han. Seoul: Dap Gae.

Kim, S., 1988. Journey to Mujin. Seoul: The Korean Culture and Arts Foundation.

Kim, Y., 2010. I Have the Right to Destroy Myself. Paju: Munhakdongne Publishing Corp.

Lee, H., 1965. Petit Bourgeoisie. Seoul: Singu Publising.

Pak, K., 2002. Markt und Krieg. Translated by Helga Picht and Jeunggeun Kim. Osnabrück : Secolo Verlag.

Shin, D., 1963. Asanyeo. Seoul: Munhaksa.

Yun, H., 2001. The Man Who Was Left as Nine Pairs of Shoes. Translated by Bruce Fulton and Ju-Chan Fulton. Wonju: Asia publishers.

\section{Articles in journals:}

Bang, M.H., 2015. From the Maelstrom of the Korean War. In: _ list Books from Korea, vol . 28, pp.34-35.

Hong, Y.H., 2015. Literature Takes Up the Fight for the Freedom and Equality. In: _ list Books from Korea, vol . 28, pp.36-37.

Kim, J.H., 2015. The Flow of Korean Literature through the Eras. In: _list Books from Korea, vol . 28, pp.30-33.

Kim, J. M., 2013. Cultural correspondence of Korean War in 1960's - focused on filmic translations of The Wounded and The General's Mustache. In: Study of the Popular Narrative, vol. 19, pp.73-75.

Pempel, T.J. 2008. Korean Studies in the United States: A Comparative Perspective from Berkley. In: Yang, S.H. and Choi, Y.S. and Choi, J.K. (ed.), 2008. Korean Studies in the World. Seoul: Jimundang. pp.1-20.

Ryoo, B.S., 2015. Towards Rupturing the Symbolic Order. In: _ list Books from Korea, vol . 28, pp.40-41.

Shin, S.J., 2015. Modern Existence and the Investigation of Sexuality. In: _list Books from Korea, vol . 28, pp.44-45. 
Sung, S.Y., 2008. Why are Asians attracted to Korean pop culture? In: The Korea Herald (ed.) Korean Wave, Insight into Korea Series vol. 5. Paju: Jimoondang, pp.11-21.

\section{Endnotes}

1 The representative works for these themes were published by Wonil Kim's The Spirit of Darkness (1973), Sangguk Cheon's The Restless Villages (1977), Sungwon Han's La mer de brouillard (1979), Munyol Yi's The Son of Man (1979) and so on.

2 Poet Kwangkyu Kim, born in 1941 in Seoul, debuted at a rather late 34 years of age in the journal Literature and Intelligence. He proved everyone's fears groundless through his prodigious poetic output. With his first collection, The Last Dream to Drench Us (1979), he expressed just how faithfully he had been carrying out his duties as a poet.

3 An interview between journalist Seohyun Ahn and poet Kangkyu Kim, Cherishing the Language of Everyday Lives, in:_list Books from Korea, vol. 28, Korea 2015, p.11.

4 Chanje $\mathrm{Wu}$, The political unconsciousness in the imagination of anxiety, Korean Literature Theory and Criticism, vol. 9, Korea 2005, pp.119-146.

5 Sokyong Hwang, The Road to Sampo, translated by U-Chang Kim, Asia Publishers, 2012, pp.19-20.

6 Youngsoon Song, Observation on parody of pansori in Kim Jiha's <ojeok; in English Five Thieves>, Korean Modern Literary Criticism, vol. 23, Korea 2007, pp.5-25.

7 Youngha Kim, I Have the Right to Destroy Myself, translated by Chiyoung Kim, Harcourt Books, 2007, p.20

\section{About Author}

\section{Dr. Sanggum LI}

He is professor of Pusan National University, South Korea. During Sept. 2011 Aug. 2012 he did carry out research as a visiting professor at University of Tartu, Estonia. His research interests are German-Baltic literature and literary criticism. He is membership of Koreanische Gesellschaft für Deutsche Sprache- und Literaturwissenschaft and was former editor of Korean Critic Review. His representative works are German Baltic and Estonian Literature (academic writing; 2011), Hidden Beauty and Sorrow in Three Baltic Countries (Estonia, Latvia and Lithuania) (Essay; 2010), Fiction and Reality of the Freedom (literary criticism; 2006) etc. 